\title{
Evaluation of Five Hybrid Watermelon Varieties for Cultivation and Performance in Coastal Guyana South America
}

\author{
Rebecca Narineㄹ, Raghunath Chandranauth ${ }^{1}$, Simon Chibi ${ }^{2}{ }^{(0)}$, Oudho Homenauth ${ }^{1}$ \\ ${ }^{1}$ National Agricultural Research and Extension Institute, Ministry of Agriculture, Georgetown, Guyana \\ ${ }^{2}$ Cuso International-National Agricultural Research and Extension Institute, Ministry of Agriculture, Georgetown, Guyana \\ Email: rnarine@narei.gov.gy, rkerryc@gmail.com, simonchibi2003@gmail.com, oudhohomenauth@gmail.com
}

How to cite this paper: Narine, R., Chandranauth, R., Chibi, S. and Homenauth, O. (2019) Evaluation of Five Hybrid Watermelon Varieties for Cultivation and Performance in Coastal Guyana South America. Agricultural Sciences, 10, 538-545. https://doi.org/10.4236/as.2019.104043

Received: February 11, 2019

Accepted: April 21, 2019

Published: April 24, 2019

Copyright $\odot 2019$ by author(s) and Scientific Research Publishing Inc. This work is licensed under the Creative Commons Attribution International License (CC BY 4.0).

http://creativecommons.org/licenses/by/4.0/

cc) (i) Open Access

\begin{abstract}
The study evaluated new watermelon varieties grown in Guyana (Bonta, Sugar Doll, Santa Matilde, Delta and Sentinel) for sustainability under local conditions. The trial was conducted at Mahaica using a randomized complete block design (RCBD) with six treatments and three replicates. Data was collected on seedling emergence, flowering, fruiting and harvesting time. Data was also collected to create plant descriptors, according to the International Union for the Protection of New Varieties of Plants, for the new varieties. Average production was recorded at $54,857.6 \mathrm{Kg} / \mathrm{ha}, 76,387 \mathrm{Kg} / \mathrm{ha}, 56,940.8$ $\mathrm{Kg} / \mathrm{ha}, 65,968 \mathrm{Kg} / \mathrm{ha}$ and 22,915.2 Kg/ha for Santa Matilde, Delta, Bonta, Sentinel and Mickylee, respectively. All varieties began flowering at the same time, however, Bonta and Mickylee were the first to produce fruits. Bonta and Mickylee were also harvested at the same time (73 days after germination). Delta had the seeds with more width $(6.3 \mathrm{~mm})$ while Santa Matilde had the longest seeds $(9.4 \mathrm{~mm})$. Average brix for Santa Matilde, Delta, Bonta, Sentinel and Mickylee were 10.8, 7.9, 8.2, 6.9 and 10.4 respectively. Mickylee and Bonta had ovaries with the same average circumference of $4.5 \mathrm{~cm}$ while Delta had the average longest ovary with $2.5 \mathrm{~cm}$. Sentinel had the average thickest stem $(9.8 \mathrm{~mm})$, broadest $(19.1 \mathrm{~cm})$ and longest $(22.1 \mathrm{~cm})$ leaf. Bonta had the average longest petiole $(11.4 \mathrm{~cm})$ and Delta had the longest fruits $(51.6 \mathrm{~cm})$. Bonta could be a suitable replacement for Mickylee since there is no significant difference between the time of harvest.
\end{abstract}

\section{Keywords}

Watermelon, Diversification, Evaluation, New Cultivars, Bonta 


\section{Introduction}

Watermelon (Citrullus lanatus) is a very popular cucurbit agricultural commodity in Guyana South America, as well as worldwide. Watermelon (Citrullus lanatus) is a monoecious vine, a scrambling and trailing vine in the flowering plant family Cucurbitaceae. The species was long thought to have originated in Southern Africa, but this was based on the erroneous synonymization by [1] of a South African species with the cultivated watermelon. Citrullus lanatus, watermelon, is an annual herbaceous plant in the squash family (Cucurbitaceae) that originated in subtropical Africa, was likely domesticated in the Mediterranean region and India, and is now cultivated in temperate to sub-tropical regions worldwide for its large, juicy fruit [1].

Records for Guyana showed that watermelon production was 24,529.4 tones in 2015, a 5631.7 tones increase from 2014 records of production [2]. Guyana depends on majorly one variety, Mickylee (which is said to be indigenous to Guyana), watermelon for its production [3]. Mickylee is open-pollinated and takes approximately 88 days to maturity. Fruits typically weigh about 3 to $5 \mathrm{~kg}$ and are round in shape; it has a light green rind colour with red flesh and is tolerant to fusarium wilt and anthracnose [4]. Mickylee (indigenous and local variety of Guyana) has been grown in Guyana as back as the first documented information by National Agriculture Research and Extension Institute as early as 2009 [3]. Mickylee is the main only watermelon variety in most farmers' fields in Guyana and the abundant on the watermelon market in Guyana too. Guyana is currently aiming to become more diversified in its agriculture sector which is why new varieties of watermelons were evaluated by the National Agricultural Research and Extension Institute (NAREI) [5]. This research was conducted so as to evaluate the performance and productivity parameters of five new varieties of watermelon in Guyana, namely: Delta, Sentinel, Sugar Doll, Bonta and Santa Matilde to create diversification within Guyana watermelon industry. The Sentinel is a blocky-oblong watermelon with bright red flesh [6]. Delta is a hybrid watermelon of the royal sweet types that are oval with deep red flesh [6]. Sugar Doll is a round watermelon with dark green skin and deep red flesh, while Santa Matilde is also oblong with bright red flesh and the Bonta is round with red flesh.

The trend of climate change is already evident; it is likely that these changes will continue. It is the increasing threat of what potential impacts climate change may bring that makes the issue of addressing agricultural adaptation more serious [7]. Diversification is just one aspect of adaptability that is being focused on. Introducing new varieties of watermelons will aid in creating diversification and providing choices to the consumer.

It is through diversification that we may attain food security. The battle to attain food security is of global concern. In many countries the problem of shortage of food is addressed by the breeding of more productive crops and creating diversification. The improved performance of plants maybe manifested in higher yields, tolerance to stresses and increased nutritional value of fruits. [8] describes 
the importance of attaining food sufficiency through diversification and plant breeding. He believes that in this millennium humanity has an exceptional chance to sustain development through better crop improvement and sustainable management of biodiversity [8].

\section{Problem Statement}

Guyana lacks diversification within the watermelon industry since the country depends mainly on one variety to supply population needs. This variety is very popular; it has been well adpated to our climatic conditions and the consumers have grown to prefer it. However, Guyana need to ask the question of food security and really think of how secure Guyana really is when depending on one variety for all watermelon needs.

\subsection{Justification}

This research was therefore aimed at evaluating new varieties of watermelon. It provides a simple way to combat climate change by crop diversification. It was also done so that baseline data could be acquired on the new varieties in Guyana and that varietal diversification may be achieved and promoted.

\subsection{Hypotheses}

1) $\mathrm{H}_{0}$ - The growth and production factors of the local and imported variety will be the same.

$\mathrm{H}_{1}$ - The growth and production factors of the varieties will not be the same.

2) $\mathrm{H}_{0}$-There will be no differences in how each variety grows, looks and produces thus plant descriptors will be the same.

$\mathrm{H}_{1}$ - There will be differences amongst the plant descriptors for each variety.

\section{Research Objectives}

\subsection{General Objective}

To cultivate and evaluate new varieties of watermelon on Guyana's soil with the aim of creating varietal diversification and other options for farmers.

\subsection{Specific Objectives}

- To compare the growth and production factors of the imported varieties with that of the locally available variety.

- To create a list of plant descriptors (fruit shape, fruit surface, predominant skin colour, skin colour, flesh clour, petiole colour, plant growth type, plant growth habit, flower colour, sex type and intensity of green leaf colour ) for the imported varieties.

\subsection{Description of Methodology}

The research was conducted in two consecutive trials (2017-2018) at the Mahai- 
ca Creek area, Region 5 of Guyana, on a clayey soil type in three different farmers' plots for 2017 and 2018 seasons. It was done using a complete randomized block design with three replication and six treatments. Treatments were as follows: T1-Santa Matilde, T2-Delta, T3-Bonta, T4-Sentinel, T5-Mickylee and T6-Sugar Doll. The land preparation done included riping, ploughing and levelling of the selected area, from the farmers' fields. General agronomic practices were done throughout the duration of the project. Fruits were harvested at full maturity. Data was collected throughout the research (plant growing duration) to reflect the fruit shape and surface texture, skin colour, flesh colour, petiole colour, plant growth type, plant growth habit, flower colour, seedling emergence time, flowering, fruiting, harvest time, seed width, brix, seed length, ovary circumference, ovary length, stem thickness, leaf width, leaf length, petiole length, fruit circumference, fruit length, and fruit weight for each variety.

The data collected was analysed statistically using ANOVA and the Post Hoc Test Tukey HSD All-Pairwise Comparison to compare the means of the growth and production parameters for the varieties. The results are presented in tables and graphs.

\section{Results and Discussion}

Key to abbr:

1. Mono-Monoecious

2. Secon-Secondary

3. Predom-Predominant

4. Indeter-Indeterminate

NB: Plant descriptors adapted from International Union For The Protection Of New Varieties Of Plants [9].

Bonta fruits were round with light green skin with dark green stripes. Santa Matilde, Delta and Sentinel produced all elliptic fruits in shape with colour variations of dark and light green netted pattern, as indicated in Table 1. All of these varieties on trials have melons sport smooth skin with red flesh and shown in Table 1. They all have an indeterminate plant growth type and produce

Table 1. Plant descriptors used.

\begin{tabular}{ccccccccccccc}
\hline Variety & $\begin{array}{c}\text { Fruit } \\
\text { Shape }\end{array}$ & $\begin{array}{c}\text { Fruit } \\
\text { Surface }\end{array}$ & $\begin{array}{c}\text { Predom } \\
\text { Skin } \\
\text { Colour }\end{array}$ & $\begin{array}{c}\text { Secon } \\
\text { Skin } \\
\text { Colour }\end{array}$ & $\begin{array}{c}\text { Flesh } \\
\text { Colour }\end{array}$ & $\begin{array}{c}\text { Petiole } \\
\text { Colour }\end{array}$ & $\begin{array}{c}\text { Plant } \\
\text { Growth } \\
\text { Type }\end{array}$ & $\begin{array}{c}\text { Plant } \\
\text { Growth } \\
\text { Habit }\end{array}$ & $\begin{array}{c}\text { Flower } \\
\text { Colour }\end{array}$ & $\begin{array}{c}\text { Sex } \\
\text { Type }\end{array}$ & $\begin{array}{c}\text { Intensity of } \\
\text { Green Leaf } \\
\text { Colour }\end{array}$ \\
\hline $\begin{array}{cccccccccc}\text { Bonta } \\
\text { Santa }\end{array}$ & Circular & Smooth & Light Green & Dark Green & Red & Light Green & Indeter & Prostrate & Yellow & Mono & Medium \\
Matilde & Elliptic & Smooth & Dark Green & Light Green & Red & Light Green & Indeter & Prostrate & Yellow & Mono & Medium \\
Delta & Elliptic & Smooth & Light Green & Dark Green & Red & Light Green & Indeter & Prostrate & Yellow & Mono & Medium \\
Mickylee & Circular & Smooth & Light Green & Light Green & Red & Light Green & Indeter & Prostrate & Yellow & Mono & Medium \\
Sentinel & Elliptic & Smooth & Dark Green & Light Green & Red & Light Green & Indeter & Prostrate & Yellow & Mono & Medium \\
\hline
\end{tabular}


yellow flowers. They are all also monoecious, meaning they all produce both male and female flowers. Also as shown in Table 1 and results indicated in Table 2, they all have light green petioles with medium green leaves. The seedling emergences were all different with the Mickylee germinating 100\%, Bonta and Santa Matilde gave 80\% germination while Sentinel gave $86.7 \%$ and Delta $83.3 \%$ as shown in Table 3. This may have been so maybe because Mickylee have been grown in the area for long and is more adaptable than the rest 4 new varieties. Thus the superior in germination was reflected. All varieties began flowering at the same time. However, fruits were noticed at different times. Fruits were observed on Bonta and Mickylee at 42 days after sowing of seeds, as indicated on Table 3, 49 days after sowing of seeds for Santa Matilde and Delta and 53 days for Santa Matilde. Agronomically Bont performed the same way as Mickylee, which indicated that the new varieties can do well in the soils and climate of Guyana and even produce more in terms of yields. Bonta and Mickylee were harvested at the same time while the others were harvested at a later date. Average brix for Santa Matilde, Delta, Bonta, Sentinel and Mickylee were 10.8, 7.9, 8.2, 6.9 and 10.4, respectively (Table 3 ). The new varieties are all in the same range with the indigenous/local variety, Mickylee, with Santa Matilde being equally in brix. Taking the average fruit weight into consideration, as indicated on Figure 1, total yield per hectare would be $54,857.6 \mathrm{Kg} / \mathrm{ha}, 76,387 \mathrm{Kg} / \mathrm{ha}$, $56,940.8 \mathrm{Kg} / \mathrm{ha}, 65,968 \mathrm{Kg} / \mathrm{ha}$ and 22,915.2 Kg/ha for Santa Matilde, Delta, Bonta, Sentinel and Mickylee, respectively. The indigenous variety, Mickylee, has

Table 2. Statistical analysis results.

\begin{tabular}{ccccccc}
\hline Variety & $\begin{array}{c}\text { Ovary Circumference } \\
(\mathrm{cm})\end{array}$ & $\begin{array}{c}\text { Ovary Length } \\
(\mathrm{cm})\end{array}$ & $\begin{array}{c}\text { Stem Thickness } \\
(\mathrm{mm})\end{array}$ & $\begin{array}{c}\text { Leaf Width } \\
(\mathrm{cm})\end{array}$ & $\begin{array}{c}\text { Leaf Length } \\
(\mathrm{cm})\end{array}$ & $\begin{array}{c}\text { Petiole Length } \\
(\mathrm{cm})\end{array}$ \\
\hline Bonta & $4.5 \mathrm{a}$ & $1.9 \mathrm{bc}$ & $9.6 \mathrm{a}$ & $9.7 \mathrm{~b}$ & $11 \mathrm{c}$ & $11 \mathrm{a}$ \\
$\begin{array}{c}\text { Mickylee } \\
\text { Santa }\end{array}$ & $4.5 \mathrm{a}$ & $1.9 \mathrm{bc}$ & $7.4 \mathrm{~b}$ & $9.7 \mathrm{~b}$ & $11 \mathrm{c}$ & $11 \mathrm{a}$ \\
$\begin{array}{c}\text { Matilde } \\
\text { Delta }\end{array}$ & $4.1 \mathrm{ab}$ & $2.4 \mathrm{ab}$ & $7.7 \mathrm{~b}$ & $16.6 \mathrm{a}$ & $20.1 \mathrm{~b}$ & $8.4 \mathrm{~b}$ \\
Sentinel & $4.5 \mathrm{a}$ & $2.5 \mathrm{a}$ & $8.4 \mathrm{ab}$ & $17.5 \mathrm{a}$ & $21.8 \mathrm{ab}$ & $10.9 \mathrm{ab}$ \\
\hline
\end{tabular}

Values with the same letter, in the same column, are not significantly different from one another at p 0.05.

Table 3. Statistical comparison for the varieties.

\begin{tabular}{|c|c|c|c|c|c|c|c|c|}
\hline Variety & $\begin{array}{c}\text { Seedling } \\
\text { Emergence \% }\end{array}$ & $\begin{array}{l}\text { Days to } \\
\text { Flowering }\end{array}$ & $\begin{array}{l}\text { Days to } \\
\text { Fruiting }\end{array}$ & $\begin{array}{l}\text { Days to } \\
\text { Harvest }\end{array}$ & $\begin{array}{c}\text { Fruit Weight } \\
(\mathrm{kg})\end{array}$ & $\begin{array}{c}\text { Fruit } \\
\text { Circumference }(\mathrm{cm})\end{array}$ & $\begin{array}{c}\text { Fruit } \\
\text { Length }(\mathrm{cm})\end{array}$ & ${ }^{\circ}$ Brix \\
\hline Bonta & $80 \mathrm{~d}$ & $32.00 \mathrm{a}$ & $42.30 \mathrm{c}$ & $73.00 \mathrm{~b}$ & $7.12 \mathrm{~b}$ & $76.73 \mathrm{a}$ & $42.16 \mathrm{bc}$ & $8.15 \mathrm{~b}$ \\
\hline Mickey Lee & $100 \mathrm{a}$ & $32.00 \mathrm{a}$ & $42.10 \mathrm{c}$ & $73.00 \mathrm{~b}$ & $2.9 \mathrm{c}$ & $45.06 \mathrm{c}$ & $31.54 \mathrm{~d}$ & $10.43 \mathrm{a}$ \\
\hline Sentinel & $86.7 \mathrm{~b}$ & $32.00 \mathrm{a}$ & $48.70 \mathrm{~b}$ & $86.5 \mathrm{a}$ & $8.3 \mathrm{ab}$ & $74.70 \mathrm{a}$ & $49.27 \mathrm{ab}$ & $6.87 \mathrm{~b}$ \\
\hline Santa Matilde & $80 \mathrm{~d}$ & $31.70 \mathrm{a}$ & $53.40 \mathrm{a}$ & $87.2 \mathrm{a}$ & $6.9 \mathrm{~b}$ & $67.31 \mathrm{~b}$ & $40.38 \mathrm{c}$ & $10.77 \mathrm{a}$ \\
\hline Delta & $83.3 \mathrm{c}$ & $32.00 \mathrm{a}$ & $48.80 \mathrm{~b}$ & $87.3 \mathrm{a}$ & $9.6 \mathrm{a}$ & $43.81 \mathrm{c}$ & $51.51 \mathrm{a}$ & $7.89 \mathrm{~b}$ \\
\hline
\end{tabular}




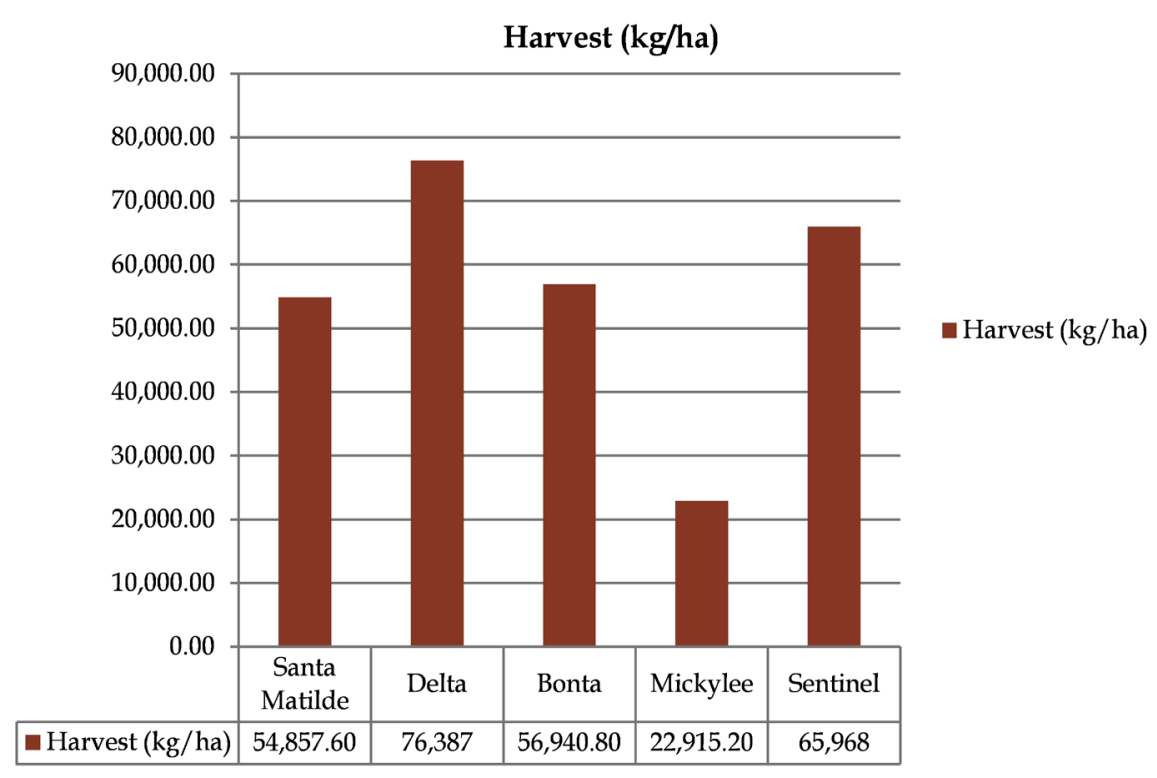

Figure 1. Yield per variety.

the least yield from all other new varieties except Sugar Doll. The new varieties outperformed the indigenous Mickylee by over $50 \%$. This reflected that the farmers can make more money by using the new varieties except Sugar Doll. The Sugar Doll variety did not produce fruits that were marketable and as such, could not have been evaluated in this research.

\section{Conclusion}

The new varieties of watermelon all have good total yield per hectare as compared to Mickylee and could have a place in Guyana markets. However, they look quite different from the well known Mickylee and market acceptability may take some time. Work may be needed to encourage farmers to cultivate these watermelons varieties. Even though farmers are acquainted with Mickylee, Bonta may be a suitable alternative since it's harvested at the same time as Mickylee (Table 2), and it has good production. The Sugar Doll maybe least suited for Guyana since the seeds did not germinate on the second trial, 2018 and with the first trial, 2017 the fruits produced were not marketable; there was no substantial yield to take data from.

\section{Recommendation}

Climate change and food security are two pressing matters of recent times. Researches are being done on a daily basis in many parts of the world to come up with ways in which the human population may be able to ensure its long term existence. Among these studies, is the task of creating diversification. The population cannot solely rely on one source of food in order to live. Here, in Guyana, diversification is slowly being learnt and new ways of enhancing it are being developed. This research was aimed at helping in the diversification process. 
Guyana mainly depends on the watermelon variety Mickylee for its watermelon needs, this has been the case for many years. But with the growing threat of climate change, there tough questions; questions that may provide equally tough answers. Questions such as how will Guyana need for the watermelon fruit are satisfied if our Mickylee variety fails to produce? The answer is simple, Guyana will not be able to meet the demands which will result in a total collapse of the industry. In a world where adaptibility is a crucial aspect of survival it is not advisable to place all eggs in one basket. Insects and diseases are evolving rapidly and a time may arise when Mickylee will not be able to withstand the pressures of changing weather and the attacks of pests and diseases. As such, it is important that other paths that will lead to the same destination are created. In this case the aim is to produce other varieties of watermelon that will give the consumer the power of choice and more importantly, diversify of watermelon industry. National Agriculture Research and Extension Institute (NAREI) is now equipped with information that it can generate to the public and further encourage the population to diversify. Farmers can now access information on the performance of other watermelon varieties besides Mickylee from NAREI and diversify in varieties of watermelon to grow in Guyana.

More experiments needs to be set to test the viability of the seeds from the harvested fruits. This will act as a source of planting materials for the next generation plants and scale up.

\section{Limitations}

The main limitation to the study was the inadequate financial resources to duplicate the same study in the more than one region of Guyana. The Mahaica creek has clayey soil which also presents some limitations on data collection and other agronomic activities during rainy days. The field were not accessible due to slippery soils and muddy on rainy days, which delayed data collection scheduled. Besides the soils, the seeds for Santa Matilde, Delta, Bonta, Sentinel and Sugar Doll all were imported seed, which researchers could not easily access for replanting and duplication in other regions. The failure of Sugar Doll results in no planting material for that variety for the scale up and other trials in different soils.

\section{Acknowledgements}

Special thanks to National Agriculture Research and Extension Institute (NAREI) for funding the research. Gratitude also goes to the farmers in Mahaica Creek area, Region 5 of Guyana for allowing the researchers to use their fields for the project.

\section{Conflicts of Interest}

The authors declare no conflicts of interest regarding the publication of this paper. 


\section{References}

[1] Bailey, L.H. (1930) Three Discussions in Cucurbitaceae. Gentes Herbarum, 2, 175-186.

[2] NAREI (2015) Annual Production Record. National Agricultural Research and Extension Institute, Georgetown, Guyana.

[3] NAREI (2011) The Farmers Manual. Ministry of Agriculture, Georgetown.

[4] Peterson, R.P. (2011) Caribbean Melon Production and Post Harvest Manual. Food and Agriculture Organisation of the United States and Caribbean Agricultural and Development Institute, Trindad and Tobago.

[5] Bryan, J. (2015) Govt. Announces Major Policy Changes to Diversify Agriculture Sector, Increase Food Exports.

http://www.kaieteurnewsonline.com/2015/08/16/govt-announces-major-policy-cha nges-to-diversify-agriculture-sector-increase-food-exports/

[6] Shrefler, J., Brandenberger, L., Rebek, E., Damicone, J. and Taylor, M. (n.d.) Watermelon Production.

http://pods.dasnr.okstate.edu/docushare/dsweb/Get/Document-1110/HLA-6236we b.pdf

[7] Howden, S.M. (2007) Adapting Agriculture to Climate Change. Food and Forestry for a Warming Climate, 104, 691-696. https://doi.org/10.1073/pnas.0701890104

[8] Osei, M. (2014) Sustainable Horticulture Systems. Springer, Cham, Switzerland.

[9] International Union for the Protection of New Varieties of Plants (UPOV) (2010) https://www.google.com/url?q=http://www.upov.int/edocs/tgdocs/en/tg142.pdf\&sa =U\&ved=0ahUKEwjLqtzdw9HeAhUyuVkKHY0jBpwQFggFMAA\&client=internaluds-cse\&cx=016458537594905406506:sa0ovkspdxw\&usg=AOvVaw3FehUlSBrl3rtH p8nTlbUe

\footnotetext{
Abbreviations

NAREI-National Agriculture Research and Extension Institute

RCBD-Complete Randomised Block Design

T-Treatment

Mono-Monoecious

Secon-Secondary

Predom-Predominant

Indeter-Indeterminate

UPOV-International Union for the Protection of New Varieties of Plants
} 